\title{
STUDI LITERATUR: EFEKTIVITAS MODEL KOOPERATIF TIPE COURSE REVIEW HORAY DALAM PEMBELAJARAN IPA DI SEKOLAH DASAR
}

\author{
Achmad Munib ${ }^{\mathbf{1}}$, Fitria Wulandari ${ }^{\mathbf{2}}$ \\ achmadmunib354@gmail.com ${ }^{1}$, fitriawulandari1@umsida.ac.id ${ }^{2}$ \\ Pendidikan Guru Sekolah Dasar, Fakultas Psikologi dan Ilmu Pendidikan, Universitas \\ Muhammadiyah Sidoarjo, Indonesia ${ }^{1,2}$
}

\begin{abstract}
Abstrak: Penelitian ini bertujuan untuk mengetahui Efektivitas model Course Review Horay dalam pembelajaran IPA di Sekolah Dasar. Metode dalam penelitian ini menggunakan penelitian kualitatif dengan teknik pengumpulan data yaitu studi literatur. Pengumpulan data yang digunakan yaitu dengan cara mengumpulkan, memeriksa informasi atau data tentang hasil penemuan yang berbeda dari buku, proposal, berbagai artikel dan jurnal yang berlaku. Data yang telah diperoleh, diteliti, dan dipusatkan di dalam dan luar secara efisien dan pada dasarnya kemudian diuraikan secara naratif. Dari hasil analisis penelitian menunjukkan bahwa nilai keaktifan dan aktivitas peserta didik dalam pembelajaran IPA menunjukkan bahwa terdapat berbedaan pemahaman peserta didik antara siklus I dan siklus II. Artinya, dari beberapa penelitian yang sudah diterapkan menggunakan model Course Review Horay ini menunjukkan bahwa dalam Efektivitas belajar yang sudah dimiliki siswa menunjukkan kurang aktif pada siklus I dan pada siklus II menunjukkan kategori aktif. Berdasarkan kajian studi literatur dapat disimpulkan bahwa model CRH dapat mempermudah peserta didik dalam pembelajaran, mampu membuat peseta didik tertarik atau senang mempelajari materi pembelajaran IPA dan model CRH ini sangat efektif diterapkan di Sekolah Dasar.
\end{abstract}

Kata kunci: course review horay, efektivitas belajar ipa, sekolah dasar.

\section{LITERATURE STUDY, THE EFFECTIVENESS OF THE COURSE REVIEW HORAY COOPERATIVE MODEL IN NATURAL SCIENCE LEARNING IN ELEMENTARY SCHOOLS}

\begin{abstract}
This study aims to determine the effectiveness of the Course Review Horay model in learning science in elementary schools. The method in this research uses qualitative research with data collection techniques, namely literature studies. Data collection used is by collecting, checking information or data about the findings that are different from books, proposals, various articles and journals that apply. Data that has been obtained, researched, and centered inside and outside efficiently and basically then described in a narrative. From the results of the research analysis showed that the value of the activeness and activities of
\end{abstract}


Achmad, Fitria. Studi Literatur, Efektivitas Model...

students in science learning showed that there were differences in the understanding of students between cycle I and cycle II. That is, from several studies that have been applied using the Course Review Horay model, it shows that the learning effectiveness that students already have shows that they are less active in cycle I and in cycle II indicate an active category. Based on the literature study, it can be concluded that the CRH model can make it easier for students to learn, is able to make students interested or happy to learn science learning materials and this CRH model is very effective in being applied in elementary schools.

Keywords: course review horay, effectiveness of learning science, elementary school.

\section{PENDAHULUAN}

Pembelajaran IPA sebagai termasuk mata pelajaran yang ada di Sekolah Dasar. Pembelajaran IPA merupakan ilmu pengetahuan alam yang mempelajari tentang peristiwa yang terjadi di alam sekitar. Salah satu tujuan dari pembelajaran IPA di sekolah dasar adalah agar siswa dapat mengembangkan tingkah laku yang positif dan pemahaman tentang keterkaitan antara alam, lingkungan salah satunya di kelas, teknologi informasi mengenai materi IPA, dan lingkungan masyarakat. Pembelajaran IPA mengarah pada rasa ingin tahu, perbuatan sehingga dapat membantu siswa dalam memperoleh pemahaman yang lebih mudah tentang kehidupan alam sekitar. Maka dari itu, agar tujuan pembelajaran IPA dapat tercapai, guru sebagai pendidik harus menyesuaikan karakteristik siswa yang berbeda itu melalui pembelajaran yang efektif.

Efektivitas sendiri merupakan bagian penting didalam materi pembelajaran IPA di sekolah dasar. Pembelajaran dapat dinyatakan efektif, apabila tujuan pembelajaran dapat tercapai sesuai target yang ingin dicapai (Pratikno \& Dewanti, 2014). Efektivitas adalah suatu ukuran yang mengukur seseberapa besar kualitas dan kuantitas yang dapat dicapai. Agar pembelajaran dapat dilakukan secara efektif, guru harus memilih dan menggunakan model pembelajaran yang tepat agar poses pembelajaran lebih efektif menciptakan suasana kelas menyenangkan sesuai dengan karakteristik siswa sehingga tujuan pembelajaran dapat tercapai. (Lapatta, Nuryanti, \& Kendek, 2015) Efektifitas pembelajaran oleh guru profesional adalah faktor utama dalam peningkatan mutu pendidikan tersebut. Guru sebagai pendidik dengan tugas utama yaitu mendidik, mengajar, membimbing, mengarahkan dan mengevaluasi peserta didik membutuhkan peningkatan profesional secara terus menerus.

Dalam suatu pembelajaran yang lebih menarik dengan menemukan dan menentukan cara yang sesuai dengan penerapan pembelajaran yang akan disampaikan kepada peserta didik tidaklah suatu hal yang mudah. (Basuki, 2019) menyatakan bahwa Proses pembelajaran yang dilakukan melalui cara yang tepat, dapat memberikan dampak positif kepada siswa khususnya 
Achmad, Fitria. Studi Literatur, Efektivitas Model...

siswa Sekolah Dasar. Suatu proses pembelajaran tentu akan membantu peserta didik memiliki cara yang sama dan waktu yang sama untuk menemukan suatu hal dalam mengatasi masalah yang ada (Lestari, 2016). Cara yang dilakukan oleh siswa dalam mengatasi berbagai masalah dalam pembelajaran dilakukan dengan cara, strategi atau pemikiran yang berbeda-beda.

Model pembelajaran merupakan sarana yang mendukung agar pembelajaran lebih efektif (Hermawan, Putro, \& Sugini, 2018). Model pembelajaran merupakan prosedur yang sistematis, berfungsi sebagai pedoman dalam merencanakan pembelajaran agar tujuan pembelajaran itu sendiri dapat tercapai dengan baik. Salah satu model pembelajaran yang cocok untuk meningkatkan efektivitas pembelajaran di Sekolah Dasar yaitu Model Kooperatif Tipe Course Review Horay. Model kooperatif merupakan suatu perilaku untuk bekerja sama dalam sebuah kelompok yang terdiri dari dua orang atau lebih, yang melibatkan setiap anggota kelompok. Guru bertindak sebagai penyampai atau pemberi materi di dalam pembelajaran berlangsung, informasi, fasilitator, serta sebagai pembimbing selama proses pembelajaran berlangsung (Mutiara, Komikesari, \& Asiah, 2019). Dengan model pembelajaran CRH ini diharapkan peserta didik dapat lebih melatih cara berpikir kreatif dalam menyelesaikan masalah secara mandiri.

Salah satu model pembelajaran yang dapat membuat siswa aktif yaitu model pembelajaran Course Review Horay. Model pembelajaran Course Review Horay sangat cocok digunakan dalam pembelajaran di Sekolah Dasar, karena sesuai dengan karakteristik siswa Sekolah Dasar. Dengan menggunakan model pembelajaran Course Review Horay ini, guru dapat menciptakan suasana yang lebih nyaman dan menyenangkan bagi siswa (Dra. Desak Putu Parmiti, 2013). Apabila siswa dapat menjawab pertanyaan yang diberikan oleh guru dengan benar, maka siswa akan memberikan teriakan "horey" atau yel-yel yang sudah disepakati guru dan siswa sebelumnya. Dengan adanya model pembelajaran CRH ini dapat membuat siswa lebih aktif dalam pembelajaran yang berlangsung, karena pembelajaran akan lebih bermakna.

Adapun kelebihan dari Model pembelajaran Course Review Horay ini yaitu strukturnya yang menarik dan dapat mendorong siswa ikut berpartisipasi secara langsung (Surabaya, 2018), model pembelajaran yang tidak monoton karena diselingi dengan hiburan, yang menbuat siswa merasa senang, semangat belajarnya meningkat, dan dapat melatih kemampuan belajar siswa agar lebih meningkat lagi dibandingkan sebelumnya yang tanpa menggunakan model pembelajaran ini. Dengan demikian pembelajaran yang menggunakan model kooperatif tipe Course Review Horay dalam pembelajaran IPA di Sekolah Dasar dapat lebih efektif. 
Achmad, Fitria. Studi Literatur, Efektivitas Model...

Penelitian ini akan menggabungkan situasi aktual untuk mengeksplorasi keefektifan model Course Review Horay dalam pembelajaran IPA sekolah dasar. Dengan cara ini, akan diperoleh hasil yang diketahui untuk meningkatkan efektivitas penggunaan model Horay Course Review ini. Kemudian tujuan dari penelitian pada Artikel ini adalah untuk mengetahui penerapan model Course Review Horay dan mendeskripsikan keefektifan model Course Review Horay dalam pembelajaran IPA sekolah dasar.

\section{METODE}

A. Jenis Penelitian

Penelitian ini menggunakan Metode penelitian Kualitatif Deskriptif dengan teknik pengumpulan data yaitu studi literatur. (Sarwono, 2006) menyatakan bahwa studi literatur yaitu pengkajian data dari berbagai buku referensi serta hasil penelitian sebelumnya yang relevan dengan penelitian untuk mendapatkan landasan teori dari masalah yang di akan teliti. Study literatur disebut sebagai penelitian perpustakaan atau penelitian pustaka. Keterbatasan kegiatan ini hanya mengarah pada produksi artikel, jurnal dan koleksi perpustakaan tanpa perlu penelitian lapangan. Penelitian ini berasal dari Buku, Jurnal Nasional atau Artikel-artikel dan Skripsi terdahulu yang se- Tema dengan penelitian ini mulai dari periode 2010.

B. Teknik Analisis Data

Analisis data yang digunakan di dalam penelitian ini merupakan model Miles dan Huberman dalam (Sugiyono, 2010) yang mengemukakan bahwa aktivitas analisis data antara lain yaitu reduksi data, penyajian data dan menarik kesimpulan. Dalam penelitian ini, pengambilan data diperoleh dari skripsi, artikel ilmiah, dan jurnal yang sesuai dengan penelitian ini, untuk dapat mengetahui Efektivitas model Course Review Horay dalam pembelajaran IPA di Sekolah Dasar, kemudian data yang sudah diperoleh kemudian dianalisis dan dikaji secara mendalam, kritis, dan sistematis yang kemudian diuraikan secara naratif.

\section{HASIL}

Efektivitas Model Kooperatif Type Course Review Horay dalam Pembelajaran IPA di Sekolah Dasar. Dalam sebuah pembelajaran IPA SD yang dilakukan dengan model Course Review Horay, pasti adanya Efektivitas yang terjadi dalam proses Pembelajarannya, terdapat empat indikator Efektivitas Belajar Siswa yaitu : 
Achmad, Fitria. Studi Literatur, Efektivitas Model...

\begin{tabular}{|c|l|}
\hline Indikator Efektivitas & \multicolumn{1}{c|}{ Deskripsi } \\
\hline $\begin{array}{c}\text { Aktivitas Siswa dalam } \\
\text { Mengikuti Pembelajaran }\end{array}$ & $\begin{array}{l}\text { Kemampuan Interaksi siswa di dalam lingkungan kelas, baik } \\
\text { proses akibat dari hasil interaksi siswa dengan guru, sehingga } \\
\text { mendapatkan hasil perubahan tingkah laku, sikap, akademik, serta } \\
\text { keterampilan yang dapat diamati dengan cara memberi perhatian } \\
\text { kepada peserta didik }\end{array}$ \\
\hline $\begin{array}{c}\text { Kemampuan guru dalam } \\
\text { mengelolah pembelajaran }\end{array}$ & $\begin{array}{l}\text { Kemampuan guru dalam melaksanakan berbagai kegiatan } \\
\text { pembelajaran agar mencapai tujuan pembelajaran itu sendiri. }\end{array}$ \\
\hline Respon Peserta Didik & $\begin{array}{l}\text { Respon peserta didik terhadap pembelajaran yang positif, } \\
\text { mendapatkan hasil angket respon peserta didik dapat digunakan } \\
\text { untuk menjawab pertanyaan mengenai materi pembelajaran yang } \\
\text { akan digunakan. }\end{array}$ \\
\hline Ketuntasan Belajar & Hasil belajar yang telah mencapai keteuntasan individual \\
\hline
\end{tabular}

Analisis ini digunakan untuk mengetahui Keefektifan model Course Review Horay dalam pembelajaran IPA di sekolah dasar. Berdasarkan analisis hasil penelitian yang dilakukan oleh (Siutriani, Arini, \& Garminah, 2016), peserta didik yang digunakan dalam penelitian yaitu peserta didik kelas $\mathrm{V}$ dengan jumlah populasi sebanyak 15 peserta didik. Pelaksanaan proses pembelajaran dengan model $\mathrm{CRH}$, siswa dibagi menjadi kelompokkelompok kecil dan pengujian pemahaman siswa menggunakan soal-soal yang berkaitan dengan materi melalui permainan pada media monopoli. Soal yang dijawab benar berarti siswa mampu memahami permasalahan maupun materi yang disampaikan. Jenis penelitian ini menggunakan Penelitian Tindakan Kelas (PTK). Dipilihnya PTK karena penelitian ini melakukan perbaikan kualitas prosesidan hasil pembelajarann dengan melakukan refleksi dan perbaikan pada tiap siklus penelitian. Sesuai dengan perencanaan yang telah disusun, pelaksanaan siklus I dan II dilaksanakan 3 kali pertemuan. Hasil penelitian Aktivitas belajar siswa di setiap pertemuan pada siklus I dan siklus II disajikan pada tabel dibawah ini, yaitu :

Tabel 1. Data Aktivitas belajar setiap pertemuan pada siklus I

\begin{tabular}{|c|c|}
\hline Pertemuan & Rata-Rata \\
\hline Pertemuan I & 12,47 \\
\hline Pertemuan II & 14,47 \\
\hline Pertemuan III & 16,20 \\
\hline
\end{tabular}

Tabel 2. Data Aktivitas belajar setiap pertemuan pada siklus II

\begin{tabular}{|c|c|}
\hline Pertemuan & Rata-Rata \\
\hline Pertemuan I & 16,20 \\
\hline Pertemuan II & 16,93 \\
\hline Pertemuan III & 17,73 \\
\hline
\end{tabular}

Berdasarkan hasil observasi pada setiap pertemuan siklus II, adapun temuan yang diperoleh selama pelaksanaan tindakan adalah sebagai berikut. (1) Proses pembelajaran telah berjalan sesuai dengan rencana pelaksanaan pembelajaran, sehingga keaktifan belajar dan hasil belajar dapat meningkat, (2) Siswa tidak lagi membeda-bedakan teman dalam 
Achmad, Fitria. Studi Literatur, Efektivitas Model...

memilih kelompok, (3) Pada pelaksanaan tindakan siklus II, siswa lebih berani dalam mengemukakan ide, bertanya, menjawab pertanyaan serta mampu bekerja sama kelompok dengan baik, dan (4) interaksi siswa dengan siswa, dan siswa dengan guru meningkat. Hasil penelitian siklus I dan siklus II dapat dilihat pada tabel 3.

Tabel 3. Data Aktivitas belajar setiap pertemuan pada siklus I dan siklus II

\begin{tabular}{|c|c|c|}
\hline Variabel & $\begin{array}{c}\text { Siklus I } \\
\mathbf{M \%}\end{array}$ & $\begin{array}{c}\text { Siklus II } \\
\text { M\% }\end{array}$ \\
\hline Keaktifan Belajar & $71,9 \%$ (cukup aktif) & $84,75 \%$ (aktif) \\
\hline Hasil Belajar & $72 \%$ (cukup) & $82 \%$ (tinggi) \\
\hline
\end{tabular}

Mengenai tabel diatas maka bisa dijelaskan bahwa :

a. Rata-rata aktivitas belajar siswa pada siklus I adalah 14,38. Persentase tingkat keaktifan belajar pada siklus I sebesar 71,9\%. Kemudian rata-rata aktivitas belajar siswa diubah menjadi PAP lima tingkat.Persentase tingkat aktivitas belajar pada siklus I berada pada kisaran $65 \mathrm{M}<80$, dan standar cukup aktif.

b. Siswa kelas V SD Negeri 4 Banyuning Bay memiliki rata-rata prestasi belajar saintifik pada siklus I sebesar 14,40 . Persentase hasil belajar saintifik pada siklus I adalah $72 \%$. Kemudian rata-rata hasil belajar tersebut dikonversikan ke dalam PAP bermata lima.Persentase hasil belajar saintifik siklus I berada pada rentang $65 \mathrm{M}<80$ yang memiliki standar cukup.

c. Rata-rata aktivitas belajar siswa pada siklus II adalah 16,95. Persentase tingkat keaktifan belajar pada siklus II adalah $84,75 \%$. Kemudian ubah rata-rata aktivitas belajar menjadi PAP lima tingkat, persentase tingkat Aktivitas belajar pada siklus II berada pada rentangan $80 \geq \mathrm{M}<90$ dengan kategori aktif.

d. Rata-rata prestasi belajar siswa pada siklus II adalah 16,40. Persentase hasil belajar saintifik pada Siklus II adalah $82 \%$. Kemudian rata-rata prestasi belajar diubah menjadi PAP tingkat 5, dan persentase prestasi belajar saintifik pada siklus II berada pada kisaran $80 \mathrm{M}<90$ yang termasuk dalam kategori tinggi.

Penelitian lain yang dilakukan oleh (Mustahidin \& Wibowo, 2016) menunjukkan bahwa penelitian ini terdiri dari 33 siswa kelas empat, termasuk 14 laki-laki dan 19 perempuan. Jenis datanya adalah data kualitatif dan data kuantitatif. Data kualitatif merupakan hasil observasi guru dan siswa, sedangkan data kuantitatif adalah data yang diperoleh dari hasil belajar siswa pada semester terakhir. Jika pada akhir siklus pembelajaran, hasil belajar siswa mengalami peningkatan, hal tersebut menandakan berhasilnya pembelajaran yaitu: 
Achmad, Fitria. Studi Literatur, Efektivitas Model...

1. Setidaknya $75 \%$ siswa telah menyelesaikan setiap indikator materi.

2. Prestasi belajar siswa pada materi minimal $75 \%$.

Rancangan penelitian terdiri dari dua siklus, dengan dua pertemuan di setiap siklusnya. Berdasarkan hasil observasi dan evaluasi yang dilakukan pada siklus I, beberapa dari kedua elemen hasil tindakan tersebut telah tercapai, namun belum berhasil. Elemen pertama hanya berhasil dengan tingkat keberhasilan $79 \%$, dan standar $21 \%$ adalah $75 \%$, sedangkan elemen kedua berhasil dengan tingkat keberhasilan $72 \%$, hingga tingkat kegagalan 28\%. Nilai rata-rata yang diperoleh pada siklus I adalah 63.

Hasil observasi dan evaluasi yang dilakukan pada siklus II menunjukkan bahwa hasil tindakan tersebut telah berhasil dari kedua aspek tersebut. Unsur pertama hanya berhasil mencapai tingkat keberhasilan 94\%, sedangkan tingkat keberhasilan 75\% tidak mencapai 6\%, unsur kedua memiliki tingkat keberhasilan 81\%, dan tingkat kegagalan sebesar 19\%, kemudian berhasil. Nilai rata-rata yang diperoleh pada siklus II adalah 75. Dari hasil analisis di atas dapat disimpulkan bahwa indeks pembelajaran yang ditetapkan peneliti berhasil.

Berdasarkan hasil Observasi Siklus II, hasil observasi meliputi kegiatan pembelajaran yang dilakukan di Tingkat IV SDN Sumber Agung Kota Serang yang menunjukkan bahwa hasil penelitian menunjukkan bahwa proses pembelajaran dengan metode pembelajaran course review horay telah mencapai kinerja sebagai berikut.

a. Aktivitas dan aktivitas guru dinilai sudah sesuai dengan model pembelajaran mata kuliah review Horay.

b. Setelah dilakukan evaluasi prestasi belajar siswa, rata-rata skor siklus II siklus I meningkat dari $72 \%$ menjadi $94 \%$.

c. Siswa merasa puas dengan model course review horay.

Tabel 4. Data Aktivitas belajar dan Hasil Belajar IPA siswa setiap pertemuan pada siklus I dan siklus II

\begin{tabular}{|c|c|c|}
\hline Variabel & $\begin{array}{c}\text { Siklus I } \\
\mathbf{M \%}\end{array}$ & $\begin{array}{c}\text { Siklus II } \\
\mathbf{M \%}\end{array}$ \\
\hline $\begin{array}{c}\text { Keaktifan } \\
\text { Belajar }\end{array}$ & $72 \%$ (cukup aktif) & $81 \%$ (aktif) \\
\hline Hasil Belajar & $79 \%$ (cukup) & $94 \%$ (tinggi) \\
\hline
\end{tabular}

Berdasarkan pengamatan di atas, siswa memberikan respon positif terhadap proses pembelajaran. Demikian pula aktivitas guru semakin nyata, dan kreativitas proses pembelajaran juga menunjukkan hal-hal yang positif. Akibat kondisi pembelajaran tersebut maka hasil belajar siswa meningkat dari siklus I ke siklus II sampai penilaian akhir 
Achmad, Fitria. Studi Literatur, Efektivitas Model... pembelajaran selesai. Pada tahap siklus I, proses pembelajaran dilaksanakan sesuai dengan rencana pembelajaran yang telah ditentukan.

Berdasarkan hasil tes akhir pembelajaran tahap II diketahui bahwa dari awal siklus pelaksanaan hasil belajar dan aktivitas siswa mengalami peningkatan karena sebagian besar siswa kurang aktif. Guru akan memberi penghargaan kepada siswa dan siswa tersebut dengan nilai tertinggi untuk alasan aktivitas siswa.

(Julia, Permatasari, \& Susilawati, 2018) Penelitian lain dilakukan dengan total 15 siswa. Implementasi penelitian ini menggunakan desain penelitian tindakan kelas (PTK). Dari dua siklus penelitian tindakan kelas. Mengamati aktivitas belajar siswa dan aktivitas mengajar guru berdasarkan data. Informasi pembelajaran dan praktik IPA siswa putaran kedua sebanyak 1.135,76 buah, dengan rata-rata 75,72 buah, yang terdiri dari 9 siswa aktif dan 6 siswa sangat aktif. Berdasarkan hasil tersebut, peneliti dan pengamat merasa puas bahwa hasil yang diperoleh telah mencapai aturan pencapaian yang diharapkan, yaitu kapabilitas dinamis 75. Informasi perseptual dari RPP analis menunjukkan bahwa rata-rata tingkat latihan putaran kedua adalah 97,62. Telah mencapai tahap yang telah ditentukan, dapat dikatakan bahwa penggunaan metode Course Review Horay dapat memperluas dan meningkatkan aktivitas belajar siswa khususnya untuk mata kuliah IPA siswa kelas tiga SD. Interaksi pembelajaran pada Siklus II diyakini telah mencapai standar yang diharapkan, dan peneliti menyelesaikan kegiatan pembelajaran dengan baik.

Tabel 4.1. Data Aktivitas belajar Siswa pada siklus I dan siklus II.

\begin{tabular}{|c|c|}
\hline Siklus & Rata-Rata \\
\hline Siklus I ke II & 14,92 \\
\hline
\end{tabular}

Tabel 4.2. Data Aktivitas belajar dan Hasil Belajar IPA Siswa pada siklus I dan siklus

II.

\begin{tabular}{|c|c|c|}
\hline Variabel & $\begin{array}{c}\text { Siklus I } \\
\text { M\% }\end{array}$ & $\begin{array}{c}\text { Siklus II } \\
\text { M\% }\end{array}$ \\
\hline $\begin{array}{c}\text { Keaktifan } \\
\text { Belajar }\end{array}$ & $61,27 \%$ (cukup aktif) & $75,72 \%$ (aktif) \\
\hline
\end{tabular}

Data penelitian ini membuktikan bahwa penerapan model Horay course review dapat meningkatkan hipotesis tindakan data aktivitas belajar ilmiah siswa kelas III SDN 7 Kebebu. Hal ini terlihat dari semua aspek aktivitas belajar siswa yang meningkat. Selain terpantau peningkatan aktivitas belajar siswa, nilai rata-rata semua indikator aktivitas belajar siswa yang diamati pada tabel observasi pada tahap pertama (61,27 dan 75,72 pada tahap kedua) juga mendukung hal tersebut, dan indeks meningkat. Perubahan tren adalah 14,92. Sehingga 
Achmad, Fitria. Studi Literatur, Efektivitas Model... dapat disimpulkan bahwa dari Siklus I ke Siklus II aktivitas belajar siswa meningkat secara signifikan.

Tabel 5. Perbandingan antara penelitian 1, 2 dan3, dapat disimpulkandalam diagram di bawah ini :

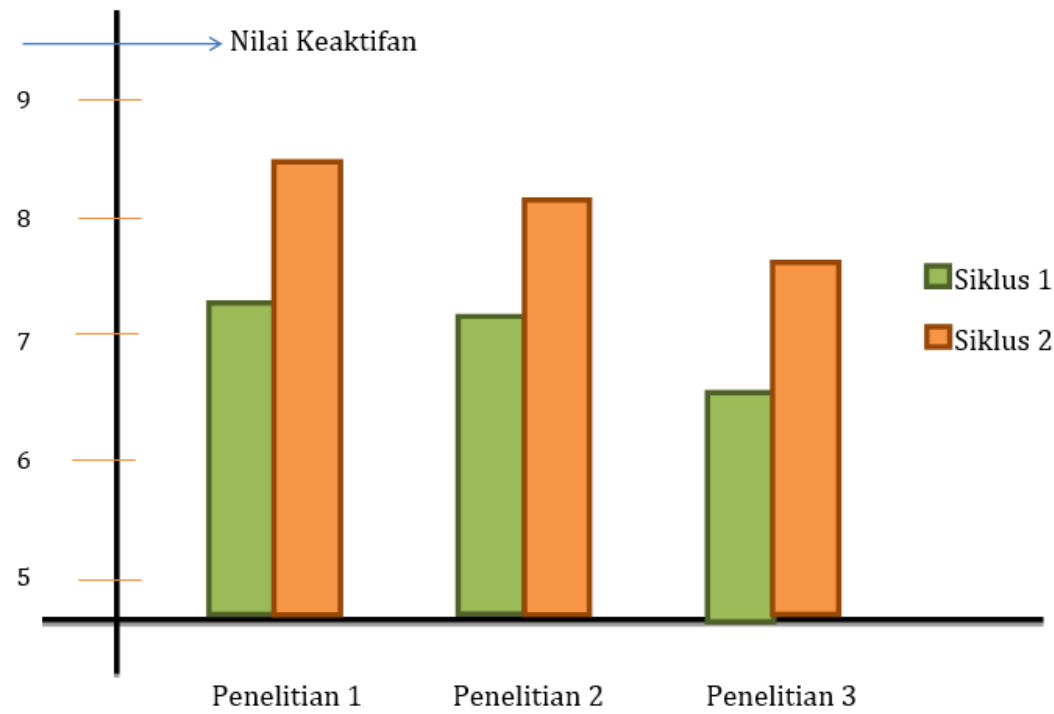

Berdasarkan Bagan di atas yaitu Penelitian 1, 2 dan 3 menunjukkan bahwa Peningkatan Aktivitas Belajar siswa dari siklus I ke siklus II, dapat dilihat bahwa terdapat perbedaan pemahaman siswa antara siklus I dan siklus II.

\section{PEMBAHASAN}

Efektivitas Model Kooperatif Type Course Review Horay dalam Pembelajaran IPA di Sekolah Dasar

Dari hasil analisis beberapa penelitian, menunjukkan bahwa nilai keaktifan dan aktivitas peserta didik dalam pembelajaran IPA menunjukkan bahwa terdapat berbedaan pemahaman peserta didik antara siklus I dan siklus II. Artinya, dari beberapa penelitian yang sudah dilakukan, menunjukkan bahwa dalam Efektivitas belajar yang sudah dimiliki siswa pada siklus I menunjukkan kurang aktif dan kategori aktif pada siklus II.

Pada saat pembelajaran siklus 1 diberikan perlakuan dengan pembelajaran konvensional yaitu pembelajaran yang ditandai dengan pengalaman yang berkaitan dengan konsep, pemberian tugas, ceramah, dan tanya jawab. Pembelajaran menggunakan ceramah dan pemberian tugas ditunjukkan pada saat guru menyajikan materi terkait, beberapa siswa melaksanakan kegiatan dengan baik dan ada siswa hanya bermain, Selain itu, pada saat kegiatan pembelajaran berlangsung tidak ada siswa yang mengajukan pertanyaan mengenai percobaan maupun materi yang disampaikan guru. Padahal, belum semua siswa paham dan 
Achmad, Fitria. Studi Literatur, Efektivitas Model... mengerti dengan materi yang disampaikan. Siswa cenderung menerima penjelasan guru tanpa adanya respon dari siswa. Ketika guru mengajukan pertanyaan, siswa yang mampu lebih mendominasi dalam menjawab pertanyaan, sehingga siswa yang kurang mampu terkesan pasif. Pembelajaran konvensional yang diterapkan guru ini tidak dikombinasikan dengan model-model pembelajaran yang inovatif, sehingga siswa pasif dalam proses pembelajaran (Rozi \& Hanum, 2019).

Setelah diberikan perlakuan menggunakan model pembelajaran course Review horay dalam pembelajaran IPA, penelitian tersebut menggunakan study hall activity research (PTK) dengan rancangan PTK (Kusfabianto, Kristin, \& Anugraheni, 2019) yang menggabungkan 4 fase kegiatan, khususnya : mengatur, melaksanakan, memperhatikan, dan merefleksikan pada siklus II, menunjukkan bahwa terdapat peningkatan Efektivitas belajar IPA dan pembelajaran yang menarik dan mendorong siswa untuk dapat terjun didalamnya, pembelajaran tidak menonton karena diselingi sedikit hiburan sehingga suasana hati saat siswa belajar tidak menegangkan, siswa lebih semangat belajar karena suasana pembelajaran berlangsung menyenangkan dan melatih kerja sama antarsiswa di dalam kelas. ketika pembelajaran peserta didik dapat menjawab pertanyaan yang diberikan oleh guru. Selain itu, peserta didik juga dapat menjelaskan dan menyimpulkan materi yang telah diberikan oleh guru sehingga tujuan pembelajaran dapat tercapai.

\section{SIMPULAN}

Melalui studi literatur dapat disimpulkan bahwa dengan menerapkan model Course Review Horay ( $\mathrm{CRH}$ ) dalam pembelajaran IPA SD, kita dapat melihat penerapan dan efektivitas model pembelajaran Course Review Horay $(\mathrm{CRH})$ dalam pembelajaran IPA SD. Dari hasil analisis penelitianimenunjukkan bahwa bahwa nilai keaktifan dan aktivitas peserta didik dalam pembelajaran IPA menunjukkan bahwa terdapat berbedaan pemahaman peserta didik antara siklus I dan siklus II. Dengan kata lain, dari beberapa penelitian yang menggunakan model Course Review Horay, Efektivitas belajar yang sudah dimiliki siswa menunjukkan bahwa mereka kurang aktif pada Siklus I, dan pada Siklus II menunjukkan kategori aktif. Penelitian yang dilakukan oleh beberapa peneliti diatas maka dapat disimpulkan bahwa dengan menerapkan, menggunakan model Course Review Horay (CRH) dalam pembelajaran IPA di sekolah dasar dapat diketahui model pembelajaran Course Review Horay $(\mathrm{CRH})$ tersebut terbukti bisa diterapkan dan efektif dipergunakan dalam pembelajaran IPA di sekolah dasar. 
Achmad, Fitria. Studi Literatur, Efektivitas Model...

\section{UCAPAN TERIMA KASIH}

Terima kasih kepada pembimbing skripsi yang telah membimbing hingga selesainya penelitian literatur ini. Terima kasih kepada keluarga besar Universitas Muhammadiyah Sidoarjo yang telah memberikan kesempatan kepada saya untuk menyelesaikan Artikel ini. Terima kasih kepada orang tua dan teman-teman di pangkuan atas doa, kerjasama dan dukungannya.

\section{DAFTAR RUJUKAN}

Basuki, K. (2019). Jurnal Online Internasional \& Nasional Vol. 7 No.1, Januari - Juni 2019 Universitas 17 Agustus 1945 Jakarta, 53(9), 1689-1699. Retrieved from www.journal.uta45jakarta.ac.id

Dra. Desak Putu Parmiti, M. . (2013). Pengaruh model Pembelajaran Kooperatif tipe Course Review Horay (CRH) terhadap Hasil Belajar Ipa pada Siswa Kelas V SD Tahun Pelajaran 2013/2014 di Gugus IV Kecamatan Buleleng. MIMBAR PGSD Undiksha, 2(1).

Hermawan, H., Putro, K. H., \& Sugini, S. (2018). The Effectiveness of Course Review Horay Method on Social Sciences Learning Achievement of Visually Impaired Students. Journal of ICSAR, 2(2), 153-157. https://doi.org/10.17977/um005v2i22018p153

Julia, A., Permatasari, R., \& Susilawati, I. (2018). Penerapan model Course Review Horay (CRH) untuk meningkatkan Keaktifan Siswa pada mata pelajaran IPA di Kelas III SDN 7 Kebebu. Jurnal Pendidikan Dasar, 6(2), 66-73. https://doi.org/10.46368/jpd.v6i2.143

Kusfabianto, I. J., Kristin, F., \& Anugraheni, I. (2019). Penerapan model Pembelajaran Course Review Horay untuk Meningkatkan Keaktifan dan Hasil Belajar Matematika Kelas IV SD. Jurnal Teori Dan Aplikasi Matematika, 3(2), 87-92.

Lapatta, J., Nuryanti, S., \& Kendek, Y. (2015). Peningkatan Hasil Belajar siswa melalui Penggunaan model Course Review Horay pada Mata Pelajaran IPA Kelas IV SD Inpres Sintuwu. Jurnal Kreatif Tadulako, 5(8), 194-207.

Lestari, N. A. P., Sudarma, I. K., \& Japa, I. G. N. (2016). Implementasi Model Pembelajaran Course Review Horay untuk Meningkatkan Aktivitas dan Hasil Belajar Siswa. Jurnal PGSD Universitas Pendidikan Ganesha, 4(1), 1-10. 
Achmad, Fitria. Studi Literatur, Efektivitas Model...

Mustahidin, A. A., \& Wibowo, E. W. (2016). Upaya Peningkatan Hasil Belajar IPA tentang Perubahan Kenampakan Bumi melalui Metode Course Review Horay. Ibtida'i: Jurnal Kependidikan Dasar, 3(2), 211-224.

Mutiara, F. B., Komikesari, H., \& Asiah, N. (2019). Efektivitas model Kooperatif tipe Course Review Horay $(\mathrm{CRH})$ terhadap Hasil Belajar Fisika Siswa. Indonesian Journal of Science and Mathematics Education, 2(1), 116-122. https://doi.org/10.24042/ijsme.v2i1.3980

Pratikno, H., \& Dewanti, S. S. (2014). Efektivitas model Pembelajaran Missouri Mathematics Project (MMP) Dilengkapi Metode Course Review Horey (CRH) terhadap Peningkatan Motivasi dan Hasil Belajar Siswa. Kaunia, 5(1), 20-29. Retrieved from http://ejournal.uin-suka.ac.id/saintek/kaunia/article/view/1062

Rozi, F., \& Hanum, C. B. (2019). Seminar Nasional Pendidikan Dasar Universitas Negeri Medan. Seminar Nasional Pgsd Unimed, 2(1), 246-311. Retrieved from https://jurnal.unimed.ac.id/2012/index.php/snpu/article/view/16127

Sarwono, J. (2006). Metode Penelitian Kuantitatif dan Kualitatif. Yogyakarta: Graha Ilmu.

Siutriani, N. W., Arini, N. W., \& Garminah, N. N. (2016). Penerapan model Course Review Horay Berbantuan Media Monopoli untuk meningkatkan Keaktifan dan Hasil Belajar IPA. E-Journal PG PAUD Universitas Pendidikan Ganesha, 4(1), 1-10. Retrieved from https://ejournal.undiksha.ac.id/index.php/JJPGSD/article/view/7271/4968

Sugiyono. (2010). Metode Penelitian Pendidikan Pendekatan Kuantitatif, Kualitatif, dan $R \& D$. Bangdung: Alfabeta.

Surabaya, U. N. (2018). Pengaruh Model Pembelajaran Course Review Horay ( CRH) Terhadap Hasil Belajar Siswa Kelas IV SDN Gilang I Pada Materi Penggolongan Hewan Berdasarkan Jenis Makanannya. 06, 1610-1620.

Huda, Miftahul. 2013. Model-Model Pengajaran dan Pembelajaran. Yogyakarta: Pustaka Belajar.

Samatowo, Usman. 2011. Pembelajaran IPA di Sekolah Dasar. Jakarta: Indeks. Cet. 2.

Samiudin. 2016. Peran Metode Untuk Mencapai Tujuan Pembelajaran. dalam JSI (Jurnal Studi Islam), Vol. 11, No. 2, 2016.

Trianto. 2013. Model Pembelajaran Terpadu. Jakarta: PT Bumi Aksara. 
Achmad, Fitria. Studi Literatur, Efektivitas Model...

Astuti, Lilin. 2016. Pemanfaatan Media dalam Pembelajaran IPA (Reporsitpry: IAIN Purokerto, Edu). 